\title{
IMPLEMENTASI E-COMMERCE PADA WEBSITE BERBASIS CMS DI ESCAPE COFFEE
}

\author{
Muhammad Erwinsyah Kala ${ }^{1)}$, Samsinar ${ }^{2)}$ \\ ${ }^{1}$ Sistem Informasi, Fakultas Teknologi Informasi, Universitas Budi Luhur \\ ${ }^{1,2} \mathrm{Jl}$. Raya Ciledug, Petukangan Utara, Kebayoran Lama, Jakarta Selatan 12260 \\ E-mail : erwinsyahkala11@gmail.com ${ }^{1)}$, samsinar@budiluhur.ac.id $^{2)}$
}

\begin{abstract}
Abstrak
Dengan pesatnya perkembangan teknologi saat ini, Website E-Commerce sangat penting dipergunakan untuk kebutuhan bisnis guna memaksimalkan kecepatan dan ketepatan bisnis pada Escape Coffee yang bergerak dalam industri perkopian, saat ini penjualan Escape Coffee hanya terbatas di wilayah sekitar toko yaitu daerah Kebayoran Baru dan kegiatan pada bisnis terdapat kendala pemasaran yang masih kurang sistematis dan tepat kepada pelanggan sehingga berakibat pada pendapatan yang menurun dan tidak stabil, untuk mengatasi masalah ini maka di buatlah Website E-Commerce berbasis Content Management System yang mudah di kelola. Pendekatan dilakukan dengan melakukan wawancara, observasi, studi literatur serta analisa dokumen. Hasil penelitian ini adalah website penjualan berbasis CMS yang dapat digunakan sebagai media penjualan dan dapat meningkatkan strategi promosi dan meningkatkan hasil dari penjualan Escape Coffee serta dapat memasarkan produk dengan cara online dan yang lebih baik, serta website yang mudah digunakan oleh konsumen dan juga admin website Escape Coffee, serta pembuatan laporan penjualan yang mudah dan sistematis.
\end{abstract}

Kata kunci: website, e-commerce, wordpress, content management system

\section{PENDAHULUAN}

Teknologi informasi kini telah berkembang sangat pesat, diiringi oleh perkembangan bisnis menggunakan metode e-commerce, dan internet pun sudah menjadi sarana media informasi bagi masyarakat dalam banyak hal, menjadikan internet sebagai sarana perdagangan adalah salah satunya, dengan ini tentu saja dapat dimanfaatkan oleh pelaku bisnis atau udaha di seluruh penuru dunia, untuk berjualan di dunia maya secara online, karena cakupan internet yang luas hinga ke seluruh dunia.

Menurut Sutrisno, Asyidiq and Santoso (2018) e-commerce adalah proses jual beli barang atau pun jasa secara online dengan menggunakan media elektronik serta internet, dengan adanya e-commerce dapat mempermudah para pelaku bisnis dan konsumen, serta sistem jual beli yang mudah dan cepat [1].

Coffee Shop atau kedai kopi merupakan suatu usaha yang menyajikan atau menjual minuman dan makanan siap saji, namun setiap kedai kopi mempunyai konsepnya masing-masing, saat ini industri perkopian di indonesia sangat berkembang pesat, mulai dari hulu sampai hilir, dan sangat diminati oleh kalangan anak muda hingga orangtua. Escape Coffee adalah sebuah perusahaan kedai kopi yang bergerak di bidang penjualan minuman dan makanan siap saji, dan juga menjual alat-alat kopi, yang terletak di daerah Darmawangsa Raya, Jakarta Selatan. Hasil observasi yang dilakukan penulis menunjukan bahwa sistem penjualan pada Escape Coffee masih terbatas hanya di kawasan Kebayoran
Baru, dan tidak ada media untuk melakukan penjualan secara online atau e-commerce.

Berdasarkan tinjauan terhadap studi mengenai e-commerce yang sudah dilakukan oleh beberapa peneliti sebelumnya yaitu sebagai berikut: "Implementasi dan Pengujian Web E-commerce untuk Produk Unggulan Desa” [2]. Berawal dari sebuah hasil kreatifitas dari sebuah desa dan melahirkan produk yang berkualitas dan dapat dipasarkan dengan cara modern, produk itu meliputi knalpot motor, knalpot mobil serta bulu mata yang bahan baku nya dibuat dari bambu, hasil analisa dari bisnis tersebut terdapat kelemahan pada sistem yang berjalan yaitu sistem penjualan dijalani oleh pengepul, pengrajin, dengan tidak adanya dukungan dokumen yang lengkap, batasan masalah pada penelitian ini adalah berbasis e-commerce, serta promosi melalui website, dengan kendala kurangnya dokumen-dokumen yang cukup. Tujuan penelitian ini adalah membuatkan sistem yang memenuhi kebutuhan dari pengguna merupakan tujuan utama dari metode pengembangan.

Menurut penelitian sebelumnya yang berjudul "Pengembangan Model Cyber Cluster E-commerce Berbasis CMS dan SEO Produk UMKM” [3]. Usaha Mikro Kecil dan Menengah (UMKM) terdapat banyak tersebar di setiap daerah atau Kabupaten di Indonesia, tetapi belum dapat berkembang dengan hasil yang memuaskan, sebagian besar UMKM mempunyai masalah utama yaitu terbatasnya kualitas sumber daya manusia yang ada dan kurangnya jaringan usaha, Begitu juga persaingan 
produk yang serupa dapat terjadi oleh antar sesama produk lokal atau produk luar negeri.

Penelitian yang berjudul "Implementasi $E$ Commerce Sebagai Media Penjualan Online"[4]. Dengan perkembangan teknologi yang maju, pada saat ini memicu para pelaku bisnis untuk berlombalomba menjadi yang terbaik, penawaran website $e$ commerce tidak hanya yang berbayar. Terdapat pula, penawaran website yang tidak berbaya juga tersedia secara gratis di Internet. Salah satu website $e$ commerce gratis tersebut adalah Opencart.

\section{METODE PENELITIAN}

\subsection{Metodologi Pengumpulan Data}

Sebuah metode pengumpulan data yang dilakukan oleh peneliti guna mendapatkan beberapa informasi dan data.

berbagai metode pengumpulan data dapat dilakukan dengan sebuah penelitian. Berikut adalah metode pengumpulan data antara lain:

a. Observasi

Metode dilakukan dengan cara terjun langsung untuk mengamati Escape Coffee secara langsung guna mendapatkan informasi penting untuk penelitian ini.

b. Wawancara

Metode ini dilakukan dengan cara memberikan beberapa pertanyaan kepada narasumber dari Escape Coffee guna mengumpulkan informasi.

c. Analisa Dokumen

Mengumpulkan data dan mencari dokumen yang terkait dalam penelitian bisa berupa dokumen penjualan, nota, ataupun invoice pembelian dan penjualan.

d. Studi Literatur

Studi literatur adalah cara untuk mengumpulkan data-data atau sumber yang berkaitan dengan topik pembahasan yang di angkat dalam sebuat penelitian.

\subsection{Teknik Analisis Data}

Merupakan suatu cara untuk menentukan suatu penelitian, berfungsi untuk menyimpulkan hasil dari penelitian serta mengolah data menjadi informasi, sehingga sifat dan karakteristik dapat mudah di pahami.

\subsection{Analisa Sistem}

Menganalisa sistem yang ada yaitu dengan menganalisa serta mengetahui apa saja yang dilakukan oleh sistem dan apa yang di gunakan nya, berikut adalah alat yang digunakan yaitu: activity diagram dan use case diagram.

Guna mempercepat proses analisis model bisnis serta untuk mengetahui kekuatan dan kelemahan dari bisnis tersebut, penulis menggunakan Business Model Canvas sebagai metode.

\subsection{Analisis Perancangan Sistem}

Tahap ini dimulai dengan merancang sistem secara rinci sehingga menghasilkan model sistem yang baru, yang memetakan struktur data dengan alat yang digunakan yaitu class diagram dan alur kerja sistem dengan System Sequence Diagram.

\section{HASIL DAN PEMBAHASAN}

\subsection{Bussiness Model Canvas}

Bisnis model canvas adalah model atau aktifitas bisnis yang terdiri dari 9 blok dan digambarkan dalam 1 lembar [5].

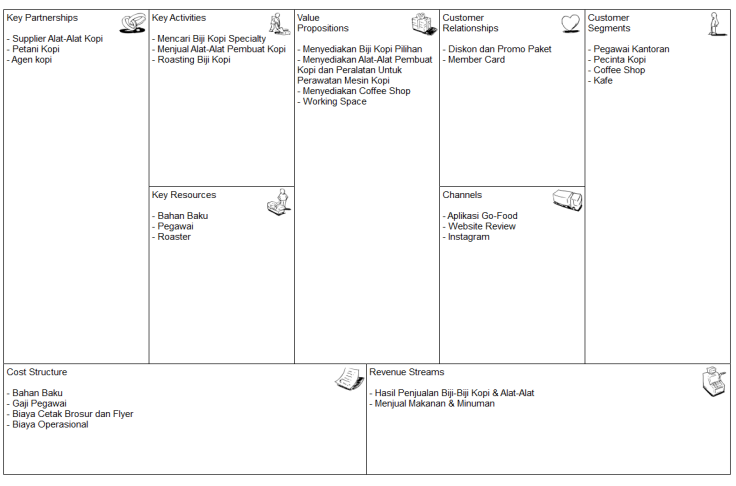

Gambar 1. Bussiness Model Canvas

Pada Gambar 1, menjelaskan 9 blok elemen dari model business dari Escape Coffee:

a. Customer Segments

Konsumen utama yang menjadi target Escape Coffee adalah pegawai kantoran, pecinta kopi, coffee shop dan kafe.

b. Value Propositions

Nilai yang ditawarkan adalah dengan menyediakan biji-biji kopi pilihan, menyediakan alat-alat kopi, menyediakan coffee shop dan working space yang nyaman.

c. Channels

Cara menjangkau konsumen dengan melalui website dan aplikasi Go-Food, Instagram dan website review.

d. Customer Relationships

Cara untuk tetap berhubungan dengan pelanggan di Escape Coffee dengan mengadakan diskon dan promo paket secara berkala dan member card

e. Revenue Streams

Keuntungan Escape Coffee didapat dari hasil penjualan dari biji-biji kopi \& alat-alat serta menjual makanan dan minuman.

f. Key Activities 
Aktivitas bisnis yang berlangsung adalah dengan menjual biji kopi specialty dan menjual alatalat pembuat kopi.

g. Key Resources

Key Resource pada Escape Coffee adalah bahan baku, pegawai, roaster.

h. Key Partnerships

Key Partnetships pada Escape Coffee adalah supplier, petani kopi, roaster.

i. Cost Structure

Pengeluaran yang untuk menjalani bisbis dari Escape Coffee adalah bahan baku, gaji pegawai, biaya cetak brosur dan biaya operasional.

\subsection{Activity Diagram}

Activity diagram menggambarkan sebuah alur kerja atau uruttan aktivitas sebuah sistem atau proses bisnis yang berjalan [6].

a. Proses Pemesanan

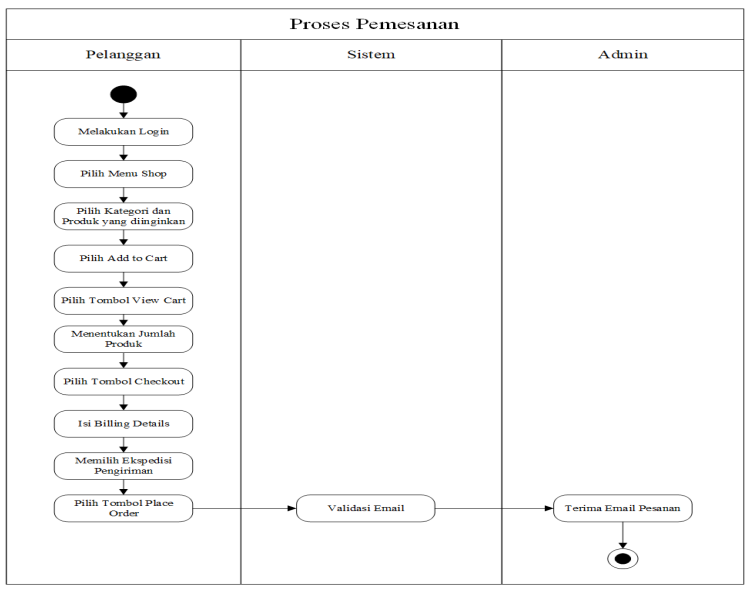

Gambar 2. Activity Diagram Proses Pemesanan

Gambar 2 activity diagram proses pemesanan, terdapat 3 actor yaitu pelanggan, sistem, dan admin. Diawali dari proses login dampai dengan melakukan pemesanan dan sistem memvalidasi email.

\subsection{Use Case Diagram}

Pada Gambar 3, menjelaskan manfaat dari sudut pandang orang atau pengguna dari luar sistem. Serta dapat menganalisa dan menggambarkan permintaan sistem [7].

a. Use Case Diagram Master

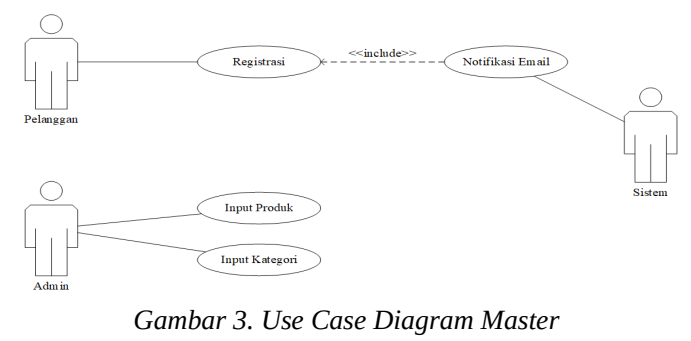

Gambar 3, use case diagram master, pelanggan dapat melakukan registrasi kemudian mendapatkan notifikasi email dari sistem, dan admin input produk beserta kategori.

b. Use Case Diagram Transaksi

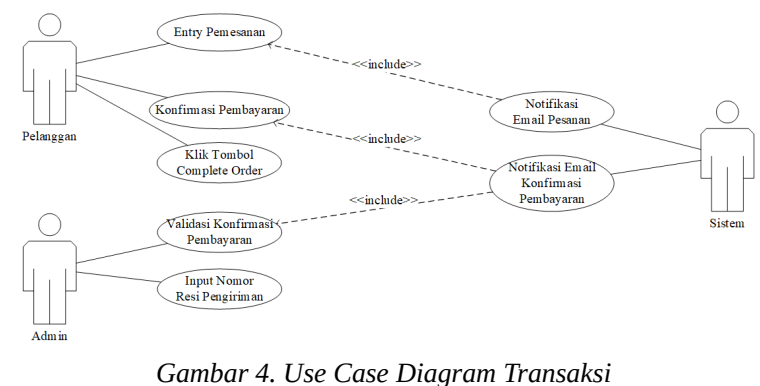

Gambar 4 yang terdiri dari 3-actor yaitu pelanggan, admin dan sistem, merupakan use case diagram proses transaksi, kemudian pelanggan dapat melakukan pemesanan serta konfirmasi pembayaran, dan admin melakukan validasi pembayaran serta menginput nomor resi pengiriman.

c. Use Case Diagram Laporan

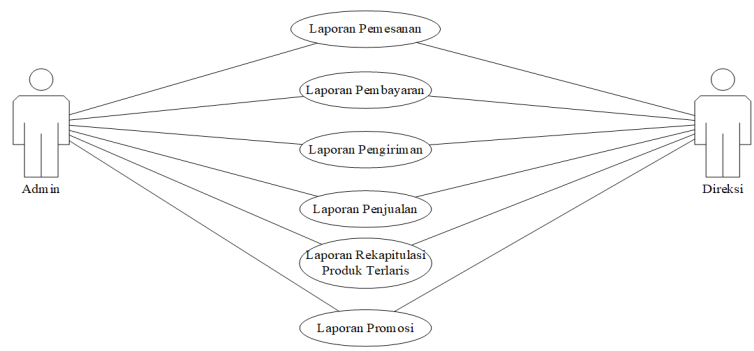

Gambar 5. Use Case Diagram Laporan

Pada Gambar 5 yang terdiri dari 2 actor yaitu admin dan direksi, admin mencetak 6-laporan yang kemudian diberikan kepada pihak direksi.

\subsection{Struktur Tampilan}

a. Struktur Tampilan Menu Pelanggan

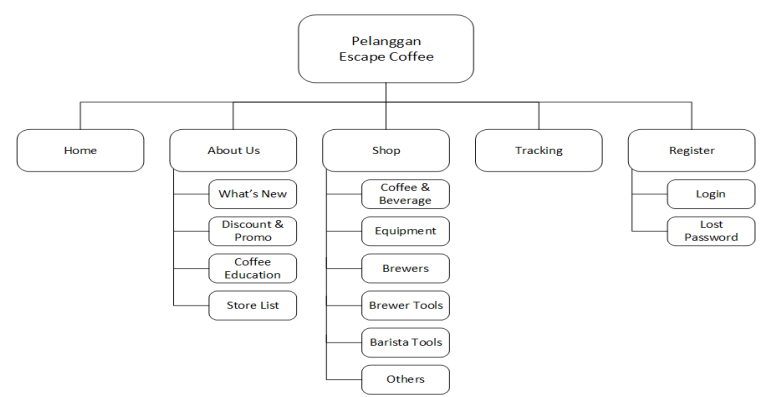

Gambar 6. Struktur Tampilan Menu Pelanggan

Gambar 6 Struktur tampilan menu dari sisi pelanggan pada website Escape Coffee.

b. Struktur Tampilan Menu Admin 


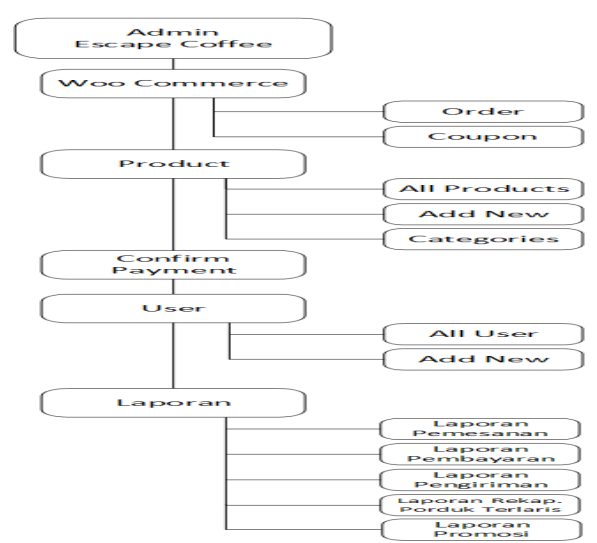

Gambar 7. Struktur Tampilan Menu Admin

Gambar 7 Struktur tampilan menu dari sisi admin website Escape Coffee yang menggunakan woocommerce.

\subsection{Tampilan Layar}

a. Tampilan Layar Cart

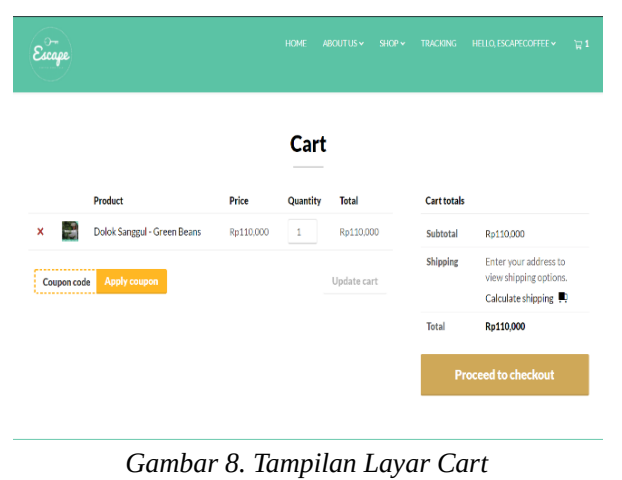

Gambar 8 Rancangan layar Cart yang menampilkan produk yang berhasil di masukan kedalam keranjang belanja yang selanjutnya akan di proses ke checkout.

b. Tampilan Layar Order Details

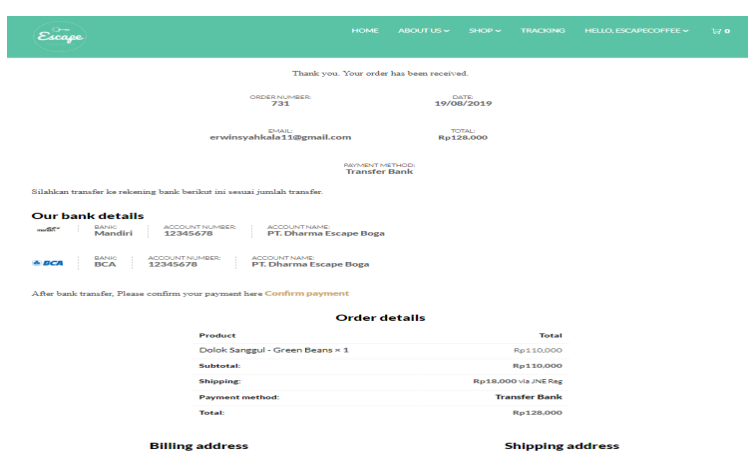

Gambar 9. Tampilan Layar Order Details
Gambar 9 adalah rancangan layar order details yang menampilkan detil order pelanggan serta terdapat link konfirmasi pembayaran untuk pelanggan.

\section{c. Tampilan Layar Confirm Payment}

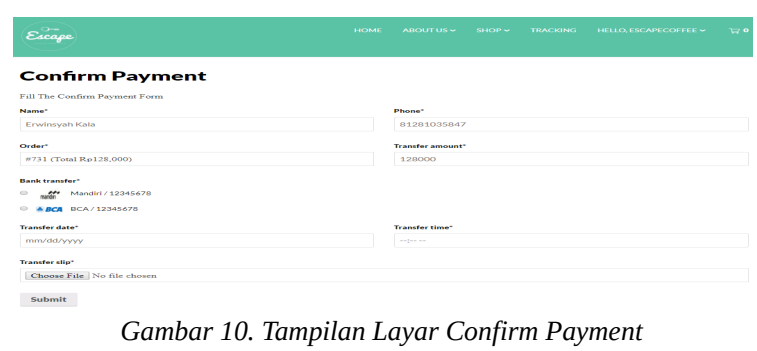

Gambar 10 Rancangan layar konfirmasi pembayaran. Terdapat kolom untuk menginput informasi mengenai konfirmasi pembayaran hingga jumlah transfer.

\subsection{Keluaran Sistem Usulan}

a. Keluaran Sistem Usulan Email Order Delivered

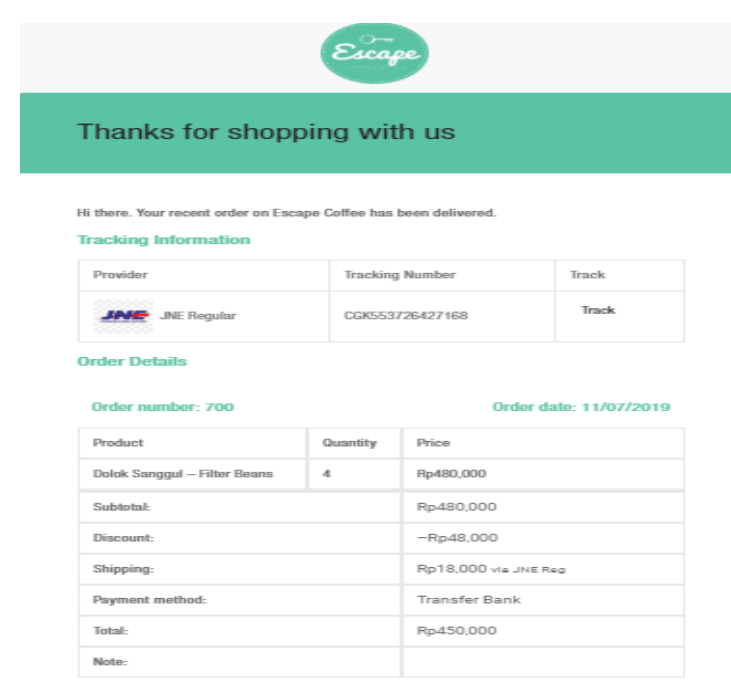

Gambar 11. Keluaran Sistem Usulan Email Order Delivered

Gambar 11 merupakan keluaran sistem usulan email order delivered, email akan otomatis terkirim setelah admin merubah status pesanan menjadi delivered.

\subsection{System Sequence Diagram}

System Sequence Diagram adalah diagram yang mentafsirkan alur kerja sebuah sistem informasi, masukan dan keluaran dari sistem [10].

a. System Sequence Diagram Registrasi Pelanggan 


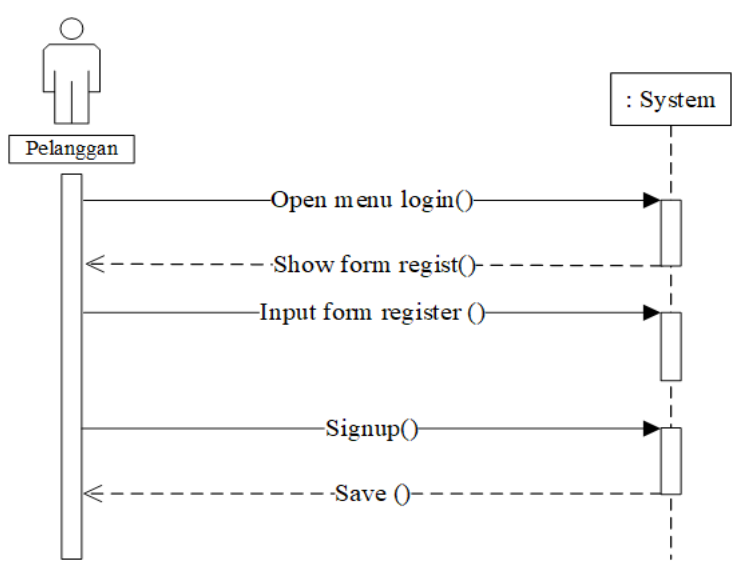

Gambar 12. System Sequence Diagram Registrasi Pelanggan

Gambar 12 mennggambarkan alur kerja sistem pendaftaran pelanggan, dimulai dari pelanggan melakukan login hingga system menyimpan datadata pelanggan kedalam database.

\section{b. System Sequence Diagram Pemesanan}

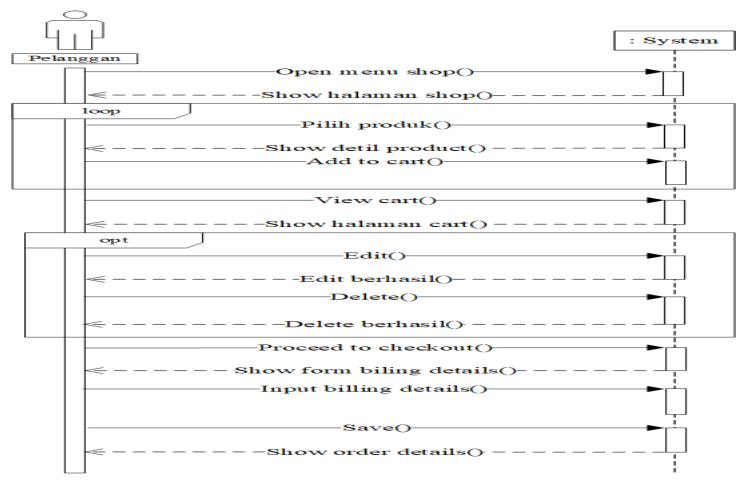

Gambar 13. System Sequence Diagram Pemesanan

Gambar 13 menggambarkar alur kerja dari pemesanan yang dimulai dari pelanggan memilih menu shop untuk memulai belanja, hingga menginput billing details dan sistem menampilkan Detil Order

\subsection{Strategi SEO dan Strategi Marketing}

Langkah-langkah strategi SEO yang diakukan adalah berikut:

1) Setting Permalink

Permalink digunakan untuk membuat link ke dalam artikel sebuah halaman website.

\section{2) Yoast SEO}

Yoast SEO membantu dalam peningkatan SEO di dalam website berbasis CMS serta mudah untuk digunakan dari sisi admin.

3) Aktivasi Google Console

Google menyediakan laporan dan data-data yang membantu untuk memahami bagaimana halaman website dapat muncul di mesin pencari dan seberapa banyak pengunjungnya.

\section{4) Title Tag}

Tittle Tag dapat membantu pengunjung website untuk mengetahui inti dari isi website atau informasi yang di sajikan.

5) Meta Description

Deskripsi lengkap mengenai apa yang di tampilkan dan di jelaskan dalam sebuah konten.

6) Focus Keyphrase

Mempermudah mengidentifikasi kata kunci yang di optimasi, dan secara otomatis akan di perbaharui.

7) Hasil SEO

Gambar 14 adalah hasil dari terapan SEO di website Escape Coffee

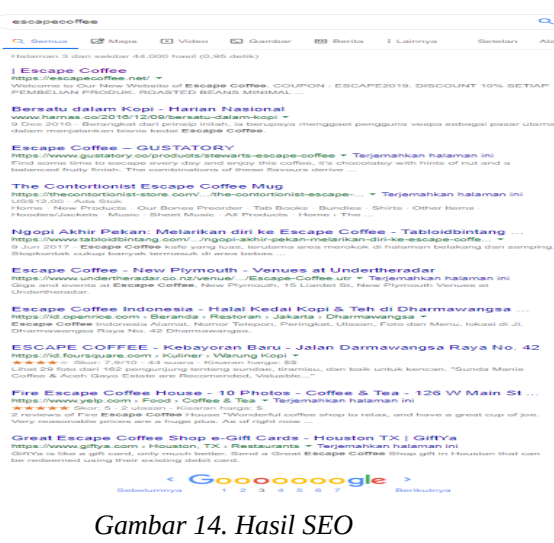

Gambar 14. Hasil SEO

\section{KESIMPULAN}

Berdasarkan penelitian yang telah dilakukan dapat diambil kesimpulakn sebagai berikut:

a. Dibuatnya website e-commerce berbasis content management system dapat memudahkan hal menawarkan atau menjual produk lebih luas dan kompleks, serta dapat memperluas wilayah promosi.

b. Menampilkan informasi produk yang menarik dan lengkap serta mudah dipahami oleh pelanggan baru

c. Dapat memberikan informasi mengenai promo-promo maupun diskon kepada pelanggan tetap ataupun pelanggan baru.

d. Website yang sangat mudah untuk digunakan (user-friendly) dari sisi pelanggan (front-end) dan mudah di kelola oleh admin (back-end).

e. Dengan menerapkan penjualan online berbasis e-commerce dapat memperluas segmentasi pasar dan memajukan di perisndustrian kopi indonesia. 


\section{DAFTAR PUSTAKA}

[1] Sutrisno, Mursalat Asyidiq, and Sugeng Santoso. () Perancangan Sistem Pemasangan Iklan Online Pada Aplikasi E-Commerce (E-Gemanusa) Menggunakan Metode Restful Api Dan Framework Laravel. Jurnal Ilmiah Sains dan Teknologi., Vol.2(2), 2018, pp. 119-132.

[2] Wahyuningrum, T. and Dwi Januarita, D. Implementasi dan Pengujian Web E-commerce untuk Produk Unggulan Desa. Jurnal Komputer Terapan. Vol. 1(1). 2015, pp.57-66.

[3] Diartono, Agus Dwi, Yohanes Suhari and Aji Spriyanto. Pengembangan Model Cyber Cluster ECommerce Berbasis CMS dan SEO Produk UMKM. Indonesian Journal of Computing and Cybernetics Systems. Vol. 9(2), 2015, pp. 145-156.

[4] Maulana, Mifta, S, Heru, and Riyadi. Implementasi E-commerce Sebagai Media Penjualan Online (Studi Kasus Pada Toko Pastbrik Kota Malang). Jurnal Administrasi Bisnis, Vol. 29(1). 2015, pp. 1-9.

[5] Athia, I., Ety Saraswati and Andi Normaladewi. Penerapan Business Model Canvas (BMC) Untuk Mendorong Mindset Kewirausahaan Di Kalangan Di Kalangan Mahasiswa Universitas Islam Malang. Jurnal Ketahanan Pangan. Vol. 2(1). 2018, pp. 66-75

[6] Siregar, Fauzi, Helmi. and Melani. Perancangan Aplikasi Komik Hadist Berbasis Multimedia. Jurnal Teknologi Informasi. Vol.2(2), 2018, pp. 113-121.

[7] Firdaus and Ade Saputra. Sistem Informasi Manajemen Pendistribusian Barang Bekas Pada UD. Yuli Mutiara Dengan Bahasa Pemrograman PHP Dan Database MySQL. Majalah. Ilmiah., Vol. 25(2). 2015, pp. 180-188. 